\title{
Benthic community metabolism in deep and shallow Arctic lakes during 13 years of whole-lake fertilization
}

\author{
William C. Daniels, ${ }^{* 1,2}$ George W. Kling, ${ }^{3}$ Anne E. Giblin ${ }^{1}$ \\ ${ }^{1}$ The Ecosystems Center, Marine Biological Laboratory, Woods Hole, Massachusetts \\ ${ }^{2}$ Department of Earth, Environmental and Planetary Sciences, Brown University, Providence, Rhode Island \\ ${ }^{3}$ Department of Ecology and Evolutionary Biology, University of Michigan, Ann Arbor, Michigan
}

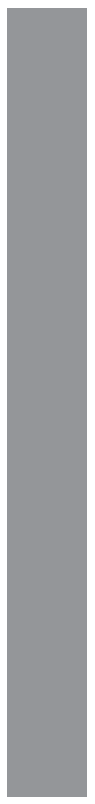

\begin{abstract}
Benthic primary production and oxygen consumption are important components of lake biogeochemical cycling. We performed whole-lake nutrient manipulations in Arctic Alaska to assess the controls of lake morphometry, nutrients, and light on benthic community metabolism. One deep, stratified lake (Lake E5) and one shallow, well-mixed lake (Lake E6) in the Alaskan Arctic were fertilized with low levels of nitrogen (56 $\mathrm{mg} \mathrm{N} \mathrm{m}^{-3} \mathrm{yr}^{-1}$ ) and phosphorus (8 $\mathrm{mg} \mathrm{P} \mathrm{m}^{-3} \mathrm{yr}^{-1}$ ) from 2001 to 2013. Benthic primary production was not stimulated by fertilization in either lake. In the deep lake, decreased water clarity is consistent with an increase in phytoplankton biomass during fertilization. Benthic GPP decreased by $7-47 \mathrm{mg} \mathrm{C} \mathrm{m}^{-2} \mathrm{~d}^{-1}$ (not statistically significant) and benthic respiration increased from $87 \pm 20$ to $167 \pm 9$ (SE) $\mathrm{mg} \mathrm{C} \mathrm{m}^{-2} \mathrm{~d}^{-1}$. The areal hypolimnetic oxygen deficit increased by $15 \mathrm{mg} \mathrm{O}_{2} \mathrm{~m}^{-2} \mathrm{~d}^{-1}$ each year during the $13 \mathrm{yr}$ of monitoring, apparently driven by lower (more negative) benthic NEP. In the shallow lake, phytoplankton concentration did not change with fertilization. As a result, the light environment did not change and benthic GPP did not decrease. Overall the data suggest that (1) benthic algae are not nutrient limited in either the deep or shallow lake, (2) lake morphometry modulated the overall nutrient impact on benthic metabolism by controlling the response of phytoplankton, and by extension, light and organic carbon supply to the benthos, (3) year-toyear variability in light attenuation explains considerable variability in benthic GPP between lakes and years, (4) correlations between both dissolved organic carbon concentrations and light attenuation coefficients $\left(k_{\mathrm{d}}\right)$ between lakes suggests a regional control on light attenuation, and (5) the dissolved oxygen concentrations in the deep experimental lake are highly sensitive to nutrient enrichment.
\end{abstract}

Quantifying the ecosystem level response to variations in nutrient loading has been the focus of many water quality and lake ecosystem studies (Schindler 1978; Howarth 1988; Morris and Lewis 1988). However, recent work on the importance of primary production by benthic algae, including epipelon, epilithon, and epiphyton, suggests that assessments of nutrient limitation based only on pelagic responses may not accurately reflect whole-lake nutrient limitation (Vadeboncoeur et al. 2001, 2003; Karlsson et al. 2009). The reason is that there is a compensatory trade-off between benthic and pelagic GPP across trophic gradients because the concentration of phytoplankton affects the amount of light available to benthic habitats (Vadeboncoeur and Steinman 2002). In most cases epipelic algae are light limited, rather than

Additional Supporting Information may be found in the online version of this article.

*Correspondence: William_daniels@brown.edu nutrient limited, and, much of the epipelon nutrient demand is met by within-sediment remineralization (Jäger and Diehl 2014). As such, nutrient addition to the water column tends to benefit phytoplankton more than benthic algae. The resulting effect of decreased water clarity can suppress benthic primary production. Nutrient addition impacts on whole-lake primary production are therefore proportionately smaller if both benthic and pelagic processes are considered than if pelagic processes are considered alone.

In lakes where benthic substrates are well-lit, either because of low background light attenuation or because they are shallow, nutrient addition can potentially stimulate benthic production while simultaneously increasing phytoplankton production and biomass (Stanley 1976; Hansson 1992; Jäger and Diehl 2014). Ultraoligotrophic lakes at high latitudes commonly fit this description. In these cases, model simulations show that the stimulation of benthic algae and benthic nutrient uptake can act to diminish the anticipated increase in phytoplankton growth (Genkai-Kato 
et al. 2012). Benthic algae are effective at trapping nutrients when water column $\mathrm{P}$ concentration is less than approximately $10 \mathrm{mg} \mathrm{P} \mathrm{m}^{-3}$, depending on background light attenuation. Below this level, increasing nutrients can either increase (Jäger and Diehl 2014) or have little effect (GenkaiKato et al. 2012) on total lake production. At phosphorus concentrations on the order of $10-100 \mathrm{mg} \mathrm{P} \mathrm{m}^{-3}$ (Jäger and Diehl 2014) or $\mathrm{P}$ loading rates of $2-5 \mathrm{mg} \mathrm{P} \mathrm{m}^{-2} \mathrm{~d}^{-1}$ (Genkai-Kato et al. 2012), phytoplankton shading overwhelms benthic productivity, benthic production decreases, and a positive feedback of sediment nutrient release further fuels planktonic production (Jäger and Diehl 2014). Above these levels, models indicate that benthic algae decline precipitously.

At the whole-lake scale, lake morphometry is an important control on the relative contribution of benthic production to total lake production (Vadeboncoeur et al. 2008; Whalen et al. 2008). The reason again relates to the light environment of the lake-benthic GPP may be relatively more important in shallow lakes because the ratio of sediments in the photic zone to the volume of the epilimnion is high. In deep lakes, especially those with steep slopes (Vadeboncoeur et al. 2008), phytoplankton may dominate the annual GPP on a whole-lake scale.

Morphometry can also influence the fate of nutrients entering a lake and the dynamic biological response to changing nutrient inputs (Fee 1979; Vadeboncoeur et al. 2008). Fee proposed that in deep and stratified lakes, phytoplankton are more likely to settle through the thermocline where the nutrients they contain are more effectively trapped in the hypolimnion. In such cases, additional nutrients may not benefit benthic algae especially considering the shading effects of increased phytoplankton biomass in surface waters. In shallow lakes with weak or no stratification, there is a balance between greater recycling of nutrients to the photic zone through physical mixing (Fee 1979; Nolen et al. 1985) and greater uptake of nutrients by benthic algae (Jäger and Diehl 2014).

In most Arctic lakes, pelagic primary production is low because the growing season is short and nutrient concentrations are low. Benthic algae therefore tend to be relatively important to whole lake production-they can fix up to $18 \mathrm{~g} \mathrm{C}$ $\mathrm{m}^{-2} \mathrm{yr}^{-1}$ (Welch and Kalff 1974) or contribute upwards of 98\% of a lake's total annual production (Vadeboncoeur et al. 2003, see also review by Quesada et al. 2008). Because of the extremely low nutrient levels in Arctic lakes, there is potential for benthic algae to be nutrient limited rather than light limited (Stanley 1976; Hansson 1992). We tested this hypothesis by performing two whole-lake fertilization experiments in ultraoligotrophic Arctic lakes. The study lakes and their unmanipulated reference lakes are located near Toolik Lake in the Arctic tundra of northern Alaska. Because the nutrient impact may depend on lake shape, as described above, the two lakes in this experiment were chosen to represent two basic morphome-

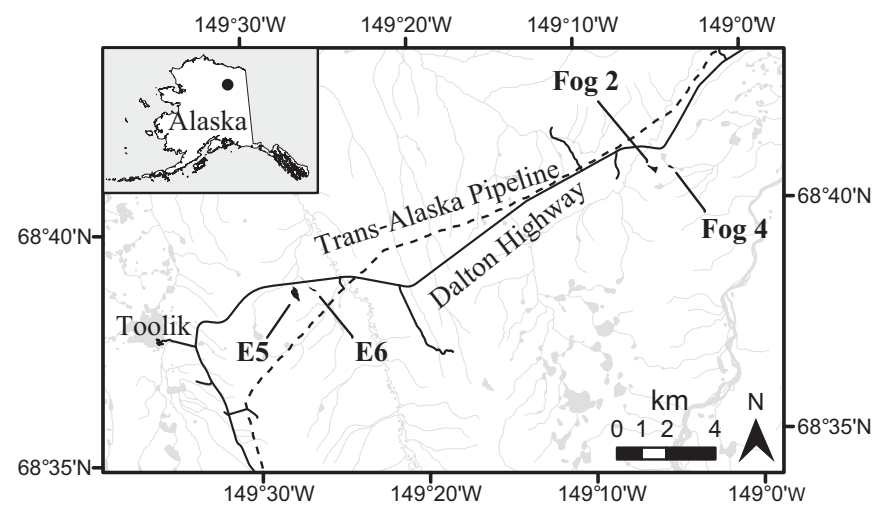

Fig. 1. Map of the study region showing locations of the fertilized lakes $(\mathrm{E} 5, \mathrm{E} 6)$ and reference lakes (Fog 2, Fog 4) and the proximity to Toolik Lake Field Station.

tries-one was shallow $\left(z_{\max }=3.2 \mathrm{~m}\right)$ and polymictic while the other was deeper $\left(z_{\max }=12.7 \mathrm{~m}\right)$ and dimictic. We hypothesized that benthic GPP would only be stimulated in the shallow lake where a greater proportion of lake floor lies above the $1 \%$ light level (100\% of lake floor in the shallow lake vs. 35\% of lake floor in the deep lake), and that nutrients added to the deeper lake would be recycled within the water column or lost to the hypolimnion during the summer growing season resulting in no effect on benthic algae.

We assessed changes in the benthic communities during the fertilization time course in both experimental and both reference lakes by examining chlorophyll content, measured and modeled photosynthesis parameters, and respiration rates. We also calculated benthic GPP and NEP by combining the photosynthesis parameters with measured light availability, which is influenced by changes in water transparency and ambient incoming insolation.

While most Arctic lakes are not exposed to point-source nutrient pollution because of their distance from population centers, it has been suggested that global climate change will increase the delivery of nutrients from land to water (Hobbie et al. 1999). Increased nutrient loading may result from enhanced precipitation and runoff events (MacIntyre et al. 2009) or from thermally driven erosion and weathering of permafrost soils (Bowden et al. 2008; Mesquita et al. 2010; Rowland et al. 2010). Thermokarst failures exemplify one type of thermal erosion and are characterized by mass transport of soil (turbidity), vegetation, and dissolved constituents (nutrients) into surface waters.

\section{Methods}

\section{Study sites}

The four study lakes lie within $25 \mathrm{~km}$ of the Toolik Lake Field Station on the North Slope of Alaska $\left(68^{\circ} 37^{\prime} \mathrm{N}, 149^{\circ} 36^{\prime}\right.$ W, Fig. 1). Mean annual air temperature for the region is $-7^{\circ} \mathrm{C}$ and mean July temperature is $12^{\circ} \mathrm{C}$ (Cherry et al. 
Table 1. Physical and chemical properties of the study lakes. Values are from pre-fertilization monitoring in 1999 and 2000 (ARC LTER Lakes database). Epilimnion values are averages from 0-3 m water depth. PP, particulate phosphorus. $A_{e} / V_{e}$, area of eplimentic sediment/volume of epilimnion.

\begin{tabular}{|c|c|c|c|c|}
\hline & Fog 2 (reference) & Fog 4 (reference) & E5 (fertilized) & E6 (fertilized) \\
\hline Maximum depth (m) & 20.3 & 5.4 & 12.7 & 3.2 \\
\hline $\mathrm{A}_{\mathrm{e}} / \mathrm{V}_{\mathrm{e}}$ & 0.07 & 0.44 & 0.1 & 0.63 \\
\hline Secchi depth (m) & 6.8 & 2.0 & 3.5 & 2.3 \\
\hline Sp. conductivity $\left(\mu \mathrm{S} \mathrm{cm}^{-1}\right)$ & 143 & 85 & 13 & 12 \\
\hline Epilimnion PP $\left(\mathrm{mg} \mathrm{m}^{-3}\right)$ & 5 & 13 & 7 & 12 \\
\hline Epilimnion $\mathrm{Chl} \mathrm{a}\left(\mathrm{mg} \mathrm{m}^{-3}\right)$ & 1.8 & 8.1 & 5.0 & 6.1 \\
\hline Fish & Present & Absent & Present & Absent \\
\hline
\end{tabular}

2014). The study lakes are surrounded by permafrost soils with summer active layers less than $1 \mathrm{~m}$ thick. The lakes are ultraoligotrophic (Table 1; surface TP 3.8-17 $\mathrm{mg} \mathrm{m}^{-3}$; surface chlorophyll a $0.4-9.3 \mathrm{mg} \mathrm{m}^{-3}$ ) and ice free from mid-June to late-September. Dissolved organic carbon (DOC) concentrations range from $200 \mu \mathrm{mol} \mathrm{L}{ }^{-1}$ to $895 \mu \mathrm{mol} \mathrm{L}^{-1}$. The lakes represent two basic morphometries: Lake Fog 2 and E5 are classified as deep $\left(z_{\max }>12 \mathrm{~m}, Z_{\text {mean }}>5 \mathrm{~m}\right)$ and thermally stratify during summer. Lakes Fog 4 and E6 are shallow $\left(Z_{\max }<5 \mathrm{~m}, Z_{\text {mean }}<2.5 \mathrm{~m}\right)$ and the water columns are frequently mixed. Two of the lakes underwent artificial $\mathrm{N}$ and $P$ additions from 2001 until 2013. Fog 2 served as a reference lake for the deep, fertilized Lake E5. Fog 4 was intended to serve as a reference lake for the shallow, fertilized Lake E6. From 2002 to 2005, however, a small thermokarst failure occurred along its northern shoreline and a plume of sediment could be seen entering the lake. While we did not quantify the nutrient or sediment loading during this event, it is likely to have impacted the lake ecosystem rendering it unsuitable as a reference lake. Fog 4, however, did serve as an additional model system in which to examine the impact of nutrient and light disturbance on benthic production. The benthic substrate of the lakes is dominated by unconsolidated silt-sized clastic sediments. Unlike benthic communities of many polar freshwaters (Quesada et al. 2008), the benthic algae in our study lakes were not mat-forming, but instead exhibited a gradual transition from algae-rich to algae-poor moving down the sediment column. With the exception of Lake Fog 2, the sediment matrices are visibly greenish. Rocks are present along the lake margins to the depth of ice-scour (approximately $1.5 \mathrm{~m}$ ) and sparse macrophytes were observed only in Lake Fog 2.

\section{Fertilization regime}

Benthic monitoring of the lakes began in 1999 in the experimental E lakes and in 2000 in the Fog lakes. Nutrient manipulations began in 2001. For the nutrient manipulation, $\mathrm{N}$ and $\mathrm{P}$ were added at the Redfield Ratio by slowly dripping a solution of ammonium nitrate and phosphoric acid into the lakes from a raft tethered near the lakes' centers. The target fertilization rates of $56 \mathrm{mg} \mathrm{N} \mathrm{m}^{-3} \mathrm{yr}^{-1}$ and $8 \mathrm{mg} \mathrm{P} \mathrm{m}^{-3} \mathrm{yr}^{-1}$ were approximately three times larger than the background loading rates of inorganic $\mathrm{N}$ and $\mathrm{P}$ to nearby Toolik Lake (Whalen and Cornwell 1985). The fertilization increased the annual loading by approximately fourfold. For Lake E5, the amount of added $\mathrm{N}$ and $\mathrm{P}$ was scaled to the epilimnion volume only, whereas for Lake E6 the fertilization was scaled for the entire volume. On an areal basis, this equates to $280 \mathrm{mg} \mathrm{N} \mathrm{m}^{-2} \mathrm{yr}^{-1}$ and $40 \mathrm{mg} \mathrm{P} \mathrm{m}{ }^{-2} \mathrm{yr}^{-1}$ for the $5 \mathrm{~m}$ deep mixed layer in Lake E5, and $112 \mathrm{mg} \mathrm{N} \mathrm{m}^{-2} \mathrm{yr}^{-1}$ and $16 \mathrm{mg} \mathrm{P} \mathrm{m}^{-2} \mathrm{yr}^{-1}$ for the $2 \mathrm{~m}$ average depth of Lake E6. In comparison to other whole-lake fertilization experiments, the manipulation strength is quite moderate (Table 2; Björk-Ramberg and Ånell 1985; Bergmann and Welch 1990; Vadeboncoeur et al. 2001; Bettez et al. 2002; O'Brien et al. 2005). The level of enrichment in this experiment represents a low-intensity press disturbance to the lakes.

\section{Meteorological and water column data}

Hourly incident photosynthetically active radiation (PAR, 400-700 nm) was obtained from the Arctic-LTER meteorological station (ARC LTER database). Mean summer values of incident PAR were calculated using hourly data over the time period of June 15-August 31. Measurements of water column light attenuation were made every $10 \mathrm{~d}$ during the summer for the fertilized lakes. The same measurements were made 13 times each summer in Fog 2 and Fog 4. Light attenuation coefficients with depth $\left(k_{\mathrm{d}}\right)$ were calculated as the absolute value of the slope of the natural logarithm of PAR, measured at $1 \mathrm{~m}$ intervals, plotted against depth. A Hydrolab multisonde unit (DS4) was used to measure depth profiles of dissolved oxygen (DO), temperature, $\mathrm{pH}$, and conductivity at the same time that light measurements were made.

\section{Benthic metabolism}

Because most of the benthic surface area in each lake is comprised of soft sediments, we focused on characterizing 
the epipelic algal community rather than the marginal epilithic communities. We measured the oxygen flux across the sediment-water interface to estimate net ecosystem production (NEP), community respiration (R), and gross primary production $(\mathrm{GPP}=\mathrm{NEP}+\mathrm{R})$ during the ice-free season from 1999-2005, 2007, and 2009-2013. No measurements were made in Lake Fog 4 from 2009 to 2012. Two $\mathrm{O}_{2}$ flux methods were used. From 1999 to 2003, $\mathrm{O}_{2}$ flux was measured in situ using plexiglass chambers placed on the lake floor using SCUBA (see Gettel et al. 2013 for method details). From 2001 to 2013 we generated photosynthesis-irradiance (PI) curves by measuring $\mathrm{O}_{2}$ flux in sediment cores incubated in laboratory facilities at the Toolik Field Station. We compared results from these two methods in years where both were employed. Estimates of GPP from the laboratory PI incubations were on average $40 \mathrm{mg} \mathrm{C} \mathrm{m} \mathrm{m}^{-2} \mathrm{~d}^{-1}$ higher than from in-situ chamber measurements $(p=0.072)$. Respiration averaged $87 \mathrm{mg} \mathrm{C} \mathrm{m}^{-2} \mathrm{~d}^{-1}$ higher with the laboratory incubations method $(p=0.005)$. As such, the two methods are reported independently for both GPP and respiration.

Between late-June and mid-July of each core-sampling year, oxygen flux measurements were performed on 6-8 sediment cores. Sampling sites and depths were dictated in part by the substrate distribution in the lake and in part by the desire to sample sediments representative of the shallow littoral zone and the deep hypolimnetic zone. In the shallow lakes (E6 and Fog 4), epipelon were confined to depths between $1 \mathrm{~m}$ (shallower depths had rocks), and $3 \mathrm{~m}$ (maximum depth), and we sampled at approximately $1.5 \mathrm{~m}$ and $2.5 \mathrm{~m}$ depth. In the deep lakes (E5 and Fog 2), rocks extend to about $3 \mathrm{~m}$ depth and the lake basins are steep-sided. For these lakes, half the cores were taken from the epilimnetic sediments (3-4 m) and half were from the hypolimnetic sediments $(5-7 \mathrm{~m})$. The cores were $9.5 \mathrm{~cm}$ in diameter and $40 \mathrm{~cm}$ long. For each sample, we collected approximately $25 \mathrm{~cm}$ of sediment, leaving about $15 \mathrm{~cm}$ of water-filled headspace in each core. Cores were returned to the laboratory within $2 \mathrm{~h}$ of sampling and placed in water baths at in situ lake temperatures for 8-12 h prior to the start of incubation. The overlying water of each core was replaced with filtered lake water $(0.45 \mu \mathrm{m})$ to minimize the influence of pelagic particulates on oxygen flux. Cores were sealed bubblefree and a DO probe (membrane probes 2001-2009, optical probes 2010-2012) was inserted into a port in each core top. Core headspaces were gently mixed by magnetic stirrers activated by an external rotating magnet. DO probes were programmed to record DO every $5 \mathrm{~min}$. Cores were first incubated in the dark and then under multiple light intensities to generate photosynthesis-irradiance relationships. Community respiration (R) in the dark, and net ecosystem production (NEP) in the light, were calculated from the change in oxygen over time. Oxygen fluxes were converted to carbon flux assuming photosynthetic and respiratory quotients of 1.0. We assumed that $\mathrm{R}_{\text {light }}$ was equivalent to $\mathrm{R}_{\text {dark, }}$ although in some cases $\mathrm{R}_{\text {light }}$ exceeds $R_{\text {dark }}$ because of photorespiration (Bender et al. 1987).
Typically, 4-5 light levels, ranging from $<50$ to $>350$ $\mu$ mol quanta ( $\mu$ Einstein) $\mathrm{m}^{-2} \mathrm{~s}^{-1}$ were used to model GPP against PAR using Michelis-Menten kinetics (Eq. 1) for each core. We assumed GPP is a function of light-saturated GPP $\left(P_{\max }\right)$, the PAR half-saturation constant $\left(k_{1 / 2}\right)$, and the incoming PAR $(I)$. Optimized values of $P_{\max }$ and $k_{1 / 2}$ and associated error for each sampling effort were simultaneously solved using Graphpad PRISM software.

$$
G P P=\frac{\left(P_{\max } x I\right)}{k_{1 / 2}+I}
$$

Average rates of GPP at the depth of sampling were estimated by combining parameters for the above relationship with the hourly incident PAR from June 15 to August 31, and lake-specific light attenuation coefficients linearly interpolated between sampling times. Hourly PAR measurements were modified to account for reflectance off the water surface. Reflectance was calculated hourly using zenith angle of the sun (http://www.nrel.gov/midc/solpos/solpos.html, Vähätalo et al. 2000) and averaged $35.5 \%$ over the time period of interest. The resulting value agrees well with a suite of empirical values measured for lakes around the Toolik Field Station (average 30\%; ARC LTER database). For the deep lakes, Fog 2 and E5, GPP was estimated at $3.5 \mathrm{~m}$ and $6 \mathrm{~m}$ depth. For the shallow lakes, Fog 4 and E6, GPP was estimated at $2 \mathrm{~m}$ depth. Error was estimated by Monte Carlo simulation with error attributed to the photosynthetic parameters. The average and standard deviation (SD) of 500 simulations was used to characterize the GPP of each year. In addition to simulating GPP at the sampling depths, we calculated GPP on a whole lake basis by applying the P-I curves to light calculated at $1 \mathrm{~m}$ depth intervals, summing the calculated GPP, and dividing by the total surface area of each lake.

\section{Benthic chlorophyll a}

Acetone-extractable chlorophyll a (Chl a) was measured from surface sediments to help characterize the benthic algal community. While benthic Chl $a$ is not a direct measure of algal biomass, it can serve as a useful proxy for benthic algal photosynthetic capacity. From 1999 to 2003, a $2.7 \mathrm{~cm}$ diameter core was used to collect sediment samples for chlorophyll analysis in association with the GPP chamber measurements (Gettel et al. 2013). After 2003, benthic algae biomass was assessed in sediments from the cores used for the incubations. In all cases, the surface $2 \mathrm{~cm}$ from each core was homogenized, and $5 \mathrm{~mL}$ of wet sediment were subsampled and frozen. We later added $35 \mathrm{~mL}$ of $100 \%$ acetone (which, with porewater, led to a 90\% acetone solution) and extracted in the dark overnight with occasional shaking. All samples were kept frozen in the dark until analysis. Samples were analyzed spectrophotometrically, using the acidification protocol and equations of Lorenzen (1967) to correct for phaeopigments. 

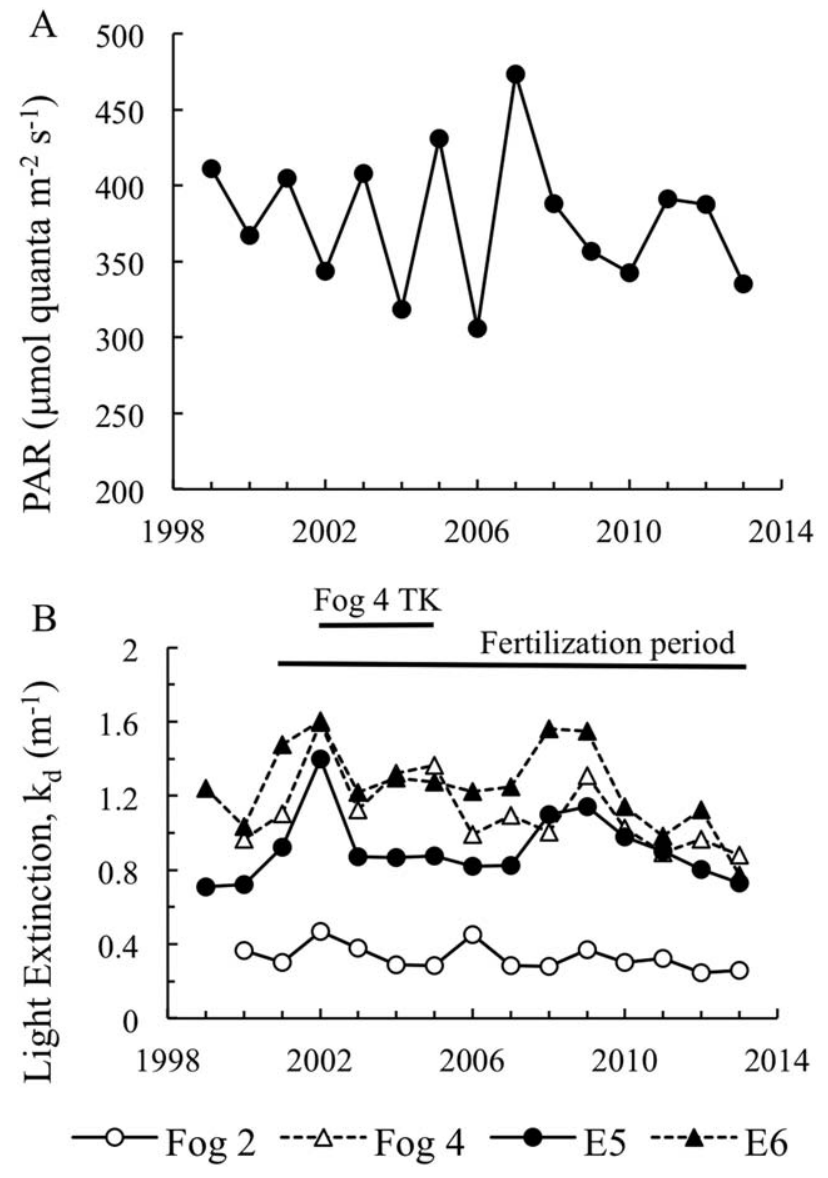

Fig. 2. (A) Average incoming PAR, measured at Toolik Field Station, from June 15 to August 31 during each year of the experiment. (B) Time series of light extinction coefficients. Points are summer averages for each year. Standard deviation within years ranged from 0.02 to 0.5 . Horizontal bars denote periods of fertilization in Lakes E5 and E6 and the thermokarst failure (TK) in Lake Fog 4.

\section{Statistical analysis}

For each fertilized lake we compared pre- and postfertilization values of benthic chlorophyll, GPP, and water column light extinction. Because it was not possible to transform all data to have normal distributions, the nonparametric Mann-Whitney rank test was used for all comparisons. For the thermokarst-impacted lake, we pooled years of active thermokarst slumping (2002-2005) and nonthermokarst years (1999-2001 and 2006-2013) for comparison. Standard errors are reported for light extinction coefficients and benthic and pelagic Chl $a$. Standard deviations are reported for benthic GPP and respiration.

\section{Results}

\section{Light environment}

Photosynthetically active radiation (PAR) incident at the water surface averaged $354 \mu \mathrm{mol}$ quanta $\mathrm{m}^{-2} \mathrm{~s}^{-1}$ from June 15 to August 31 when all years and hours of the day were pooled. There was no temporal trend in incoming PAR during the $13 \mathrm{yr}$, but there was large year-to-year variability with summer averages ranging from $306 \mu$ mol quanta $\mathrm{m}^{-2}$ $\mathrm{s}^{-1}$ in 2006 to $473 \mu \mathrm{mol}$ quanta $\mathrm{m}^{-2} \mathrm{~s}^{-1}$ in 2007 (Fig. 2a).

Light attenuation was lowest in the deep reference lake, Fog $2\left(k_{\mathrm{d}}=0.33 \pm 0.02 \mathrm{~m}^{-1}\right)$ and did not change over time (Fig. 2b). In the deep fertilized lake, E5, $k_{\mathrm{d}}$ increased significantly from $0.71 \pm 0.01 \mathrm{~m}^{-1}$ before fertilization to $0.96 \pm 0.03 \mathrm{~m}^{-1}$ after fertilization $(p<0.0009)$. Water column Chl $a$ increased from $1.7 \pm 0.06$ to $2.65 \pm 0.06 \mu \mathrm{g} \mathrm{L} \mathrm{L}^{-1}$ $(p=0.0002$, ARC LTER database). In the shallow fertilized lake, E6, $k_{\mathrm{d}}$ did not increase significantly (pre-fertilization: $1.12 \pm 0.08$; post-fertilization: $1.27 \pm 0.04 ; p=0.153)$. Water column Chl $a$ was also unchanged with fertilization (pre-fertilization: $2.1 \pm 0.06 \mu \mathrm{g} \mathrm{L}{ }^{-1}$; post-fertilization: $2.2 \pm 1.1 \mu \mathrm{g}$ $\mathrm{L}^{-1} ; p=0.23$, ARC LTER database). In the shallow, thermokarst-impacted lake Fog 4, non-thermokarst years had significantly lower $k_{\mathrm{d}}$ values of $1.02 \pm 0.05 \mathrm{~m}^{-1}$ compared to $1.38 \pm 0.15 \mathrm{~m}^{-1}$ during thermokarst years $(p=0.04)$. However, water column Chl a concentrations were not statistically higher during thermokarst years $(p=0.074)$.

\section{Deep reference Lake, Fog 2}

In the deep reference lake, Fog 2, benthic Chl $a$ in the epilimnetic sampling sites ranged from $29 \mathrm{mg} \mathrm{m}^{-2}$ to $368 \mathrm{mg}$ $\mathrm{m}^{-2}$ (average $141 \mathrm{mg} \mathrm{m}^{-2}$ to $2 \mathrm{~cm}$ depth; Fig. 3). Concentrations were similar at the deeper $(6 \mathrm{~m})$ sampling sites. At our sampling depths, benthic respiration exceeded benthic GPP in most, but not all years (Fig. 3). In this unmanipulated lake there was considerable interannual variability in PAR striking the sediment surface, as well as benthic Chl $a, P_{\max }, \mathrm{GPP}$, and respiration. The benthic variables increased from 2002 to a peak in 2007, then declined to a local minimum in 2011.

\section{Shallow reference lake, Fog 4}

Lake Fog 4 was intended as the shallow reference lake, but experienced a shoreline failure during our monitoring program. Sediment was observed slumping from a localized point along the northwest shore and mixing into the water column during four consecutive summers (2002-2005). Of our study lakes, Fog 4 had the highest concentration of benthic Chl $a$ and there was more Chl $a$ during the years of high sediment influx relative to the years with a stable shoreline-concentrations averaged $573 \pm 24 \mathrm{mg} \mathrm{m}^{-2}$ during the years of active thermokarst failure and $361 \pm 40 \mathrm{mg} \mathrm{m}^{-2}$ during the non-thermokarst years $(p=0.0001$, Table 3$)$. Years in which the shoreline failure was an active sediment source were also characterized by lower rates of benthic GPP $\left(105 \pm 59 \mathrm{mg} \mathrm{C} \mathrm{m}^{-2} \mathrm{~d}^{-1}\right.$ compared to $235 \pm 106 \mathrm{mg} \mathrm{C} \mathrm{m}^{-2}$ $\mathrm{d}^{-1}$ for years with no thermokarst activity; $p<0.0001$ ) (Table 3; Figs. 3). Respiration was variable during the thermokarst disturbance, but on average was lower than years without thermokarst activity $\left(223 \pm 77 \mathrm{mg} \mathrm{C} \mathrm{m}^{-2} \mathrm{~d}^{-1}\right.$ compared to $\left.347 \pm 88 \mathrm{mg} \mathrm{C} \mathrm{m}^{-2} \mathrm{~d}^{-1} ; p=0.0024\right)$. 

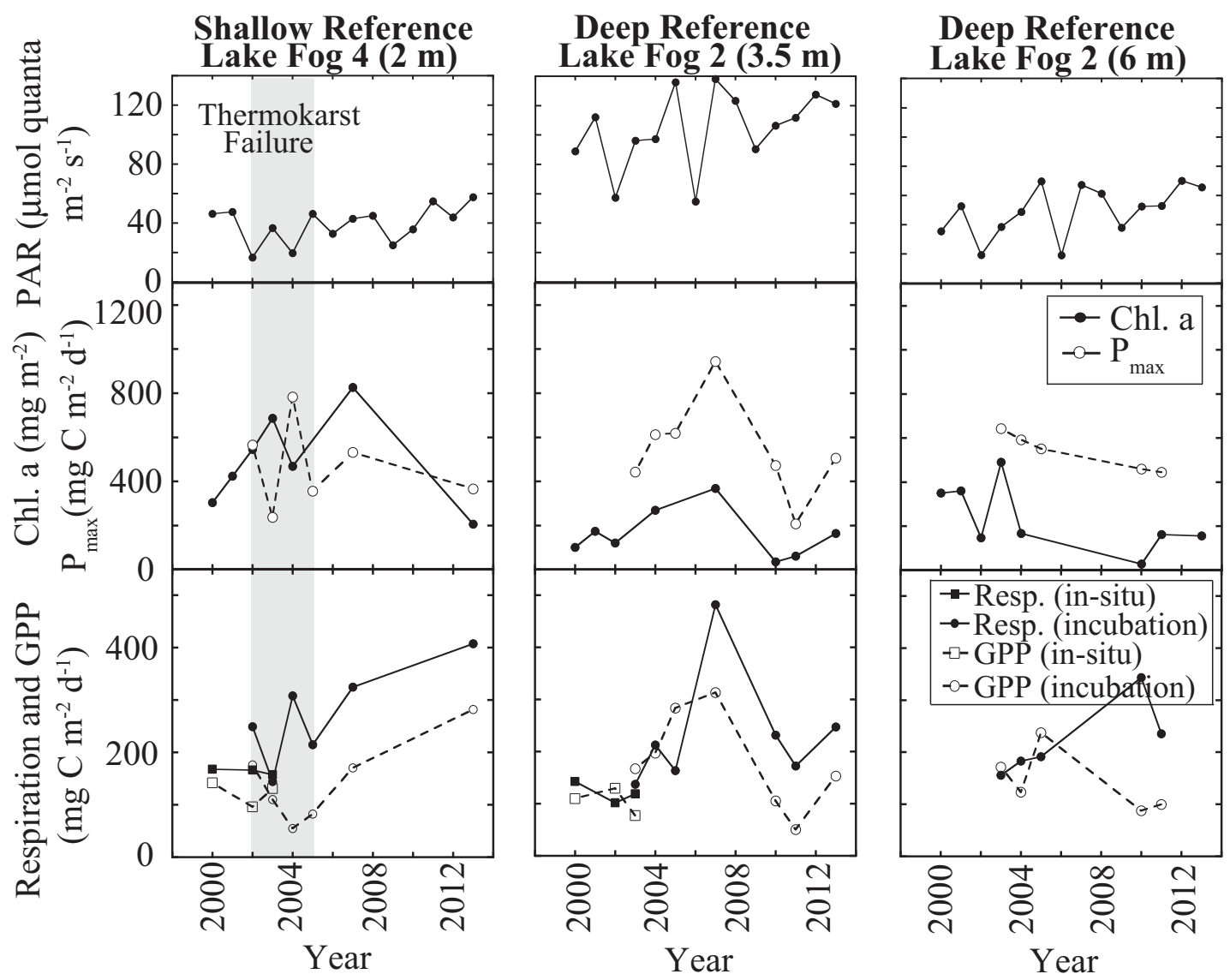

Fig. 3. Benthic data from the shallow reference Lake Fog 4 and the two sampling sites in the deep, reference lake, Fog 2. Top panel: Average PAR from June 15 to August 31 at the sampling depth ( $2 \mathrm{~m}$ for Fog 4, 3.5 and $6 \mathrm{~m}$ for Fog 2). Middle panel: Benthic Chl $a$ and modeled $P_{\text {max }}$ from core incubations. Bottom panel: Benthic respiration and GPP. Vertical gray bar in Lake Fog 4 panels represents years with an observed sediment plume.

\section{Deep fertilized lake, E5}

In the deep fertilized lake, E5, chlorophyll concentrations in the epilimnetic sediments were $139 \pm 7 \mathrm{mg} \mathrm{m}^{-2}$ in 1999 and 2000, and $179 \pm 13 \mathrm{mg} \mathrm{m}^{-2}$ after fertilization, which was not a statistically significant change $(p=0.75$, Table 3$)$. There was less year-to-year variation in Chl $a$ in this lake compared to the other lakes, but we note that, as in the deep reference lake, both $\mathrm{Chl} a$ and $P_{\max }$ increased from 2002 to 2007, and declined in the following $3 \mathrm{yr}$ (Fig. 4). Based on in situ chamber measurements, the prefertilization GPP in the deep manipulated lake, E5, was $68 \pm 13 \mathrm{mg} \mathrm{C} \mathrm{m}^{-2} \mathrm{~d}^{-1}$. The in situ chamber measurements in the $2 \mathrm{yr}$ after the fertilization began were unchanged (Gettel et al. 2013). After incorporating the longer time series of simulated GPP, we found that GPP remained unchanged during the fertilization period ( $p=0.32$; Table 3 ) although considering the change in methodology, where lab incubation estimates of GPP averaged $40 \mathrm{mg} \mathrm{C} \mathrm{m}^{-2} \mathrm{~d}^{-1}$ higher than the in situ chamber measurements for the same time periods, it is possible that fertilization induced a reduction in benthic GPP. Respiration rates were $87 \pm 28 \mathrm{mg} \mathrm{C} \mathrm{m}^{-2}$ $\mathrm{yr}^{-1}$ in 1999 and 2000 and $167 \pm 80 \mathrm{mg} \mathrm{C} \mathrm{m}^{-2} \mathrm{~d}^{-1}$ during the fertilization period $(p=0.11)$, which suggests that fertilization induced a positive change in benthic respiration. Benthic net ecosystem production was substantially lower during the fertilization period (Table 3). Hypolimnetic (6 m depth) GPP averaged $8 \mathrm{mg} \mathrm{C} \mathrm{m}^{-2} \mathrm{~d}^{-1}$ and respiration averaged $185 \pm 94 \mathrm{mg} \mathrm{C} \mathrm{m}^{-2} \mathrm{~d}^{-1}$ during the fertilization period. No pre-fertilization data is available from the hypolimnetic site of this lake.

\section{Shallow fertilized lake, E6}

In the shallow fertilized lake, E6, Chl $a$ increased from $126 \pm 13 \mathrm{mg} \mathrm{m}^{-2}$ in pre-fertilization years to $212 \pm 12 \mathrm{mg}$ $\mathrm{m}^{-2}$ after the onset of fertilization ( $p=0.02$, Fig. 4 ), although in the last $3 \mathrm{yr}$ of monitoring, Chl $a$ had returned to prefertilization levels. In situ chamber data revealed no difference in GPP with fertilization for the shallow lake, E6 (Gettel et al. 2013). The longer-term GPP measurements made from core incubations also show no statistically significant change upon fertilization-GPP was $62 \pm 46 \mathrm{mg} \mathrm{C} \mathrm{m}^{-2} \mathrm{~d}^{-1}$ prior to fertilization and $131 \pm 147 \mathrm{mg} \mathrm{C} \mathrm{m}^{-2} \mathrm{~d}^{-1}(p=0.19)$ after fertilization. 

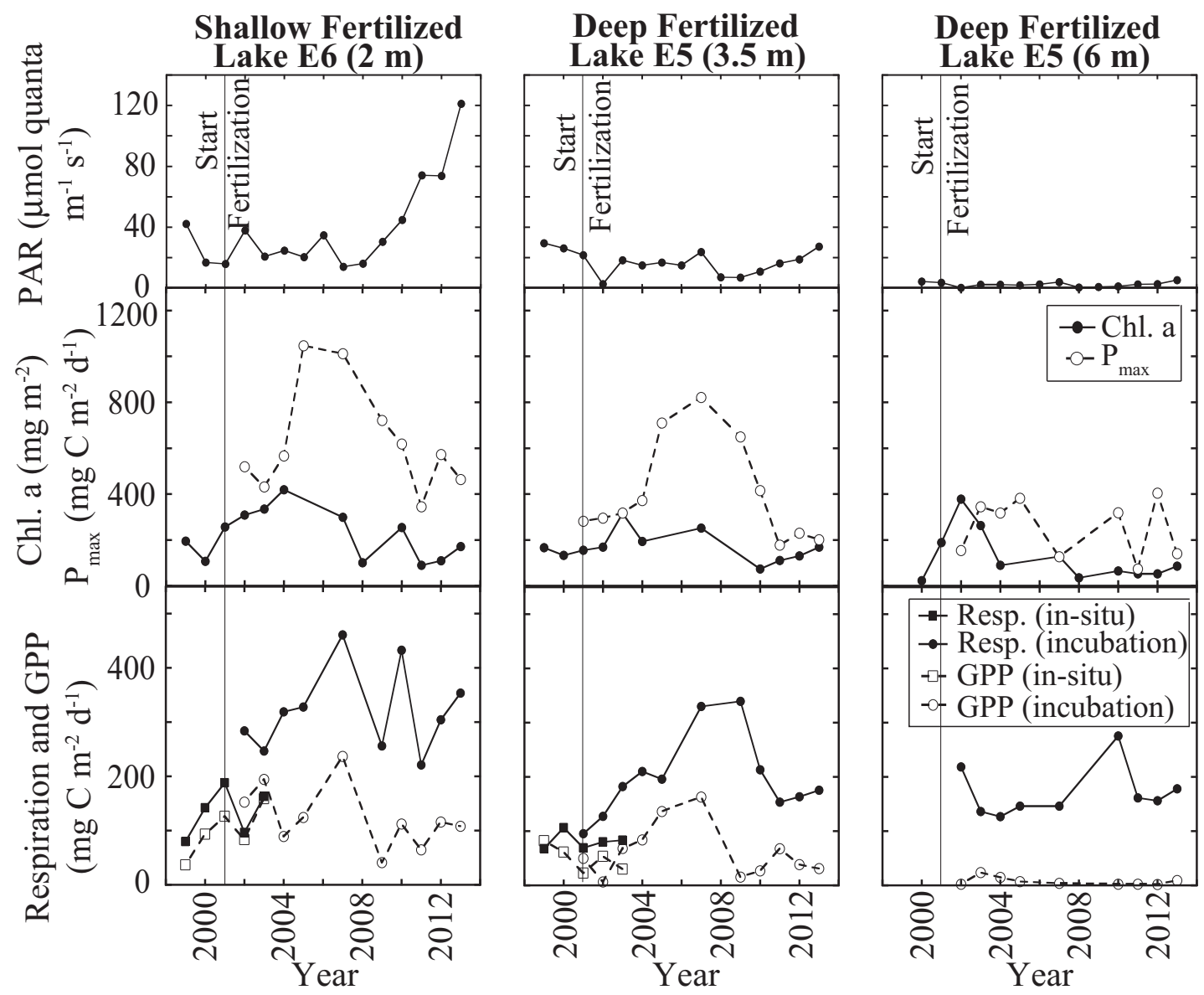

Fig. 4. Same as in Fig. 3, but for the fertilized E lakes. Measurements in the shallow lake, E6, were taken at $2 \mathrm{~m}$ depth and in the deep lake, E5, at 3.5 and $6 \mathrm{~m}$ depth. The vertical bar in 2001 represents the first year of fertilization.

Taking into account the change in methodology described above, GPP only increased by approximately $30 \mathrm{mg} \mathrm{C} \mathrm{m}^{-2}$ $\mathrm{d}^{-1}$. Respiration rose from a pre-fertilization average of $111 \pm 35 \mathrm{mg} \mathrm{C} \mathrm{m} \mathrm{m}^{-2} \mathrm{~d}^{-1}$ to a post-fertilization average of $297 \pm 157 \mathrm{mg} \mathrm{C} \mathrm{m}^{-2} \mathrm{~d}^{-1}(p=0.0007)$. However, considering the methods change, the respiration increased by approximately $107 \mathrm{mg} \mathrm{C} \mathrm{m}^{-2} \mathrm{~d}^{-1}$ from pre- to post-fertilization and there was no clear temporal trend in respiration in either the chamber or core data alone.

\section{Benthic photosynthesis parameters}

From the photosynthesis vs. irradiance curves, the average $P_{\max }$ for all lakes and years was $495 \mathrm{mg} \mathrm{C} \mathrm{m}^{-2} \mathrm{~d}^{-1}$ and the average $k_{1 / 2}$ was $163 \mu \mathrm{mol}$ quanta $\mathrm{m}^{-2} \mathrm{~s}^{-1}$. From $P_{\max }$ and $k_{1 / 2}$ values, we calculated the quantum efficiency (mol C fixed mol quanta ${ }^{-1}$ ) for the sub-saturating part of the P-I curves. The efficiency ranged from 0.0001 mol $\mathrm{C}$ per mol quanta to 0.014 mol $\mathrm{C}$ per mol quanta (Fig. 4) with an average for all lakes and sampling dates of $0.004 \mathrm{~mol} \mathrm{C}$ mol quanta $^{-1}$. Quantum efficiency was significantly related to benthic Chl $a$ across all lakes in the post fertilization period (Fig. 6). Unfortunately, estimates of $P_{\max }$ and $k_{1 / 2}$ are not available from the chamber measurements made before fertilization started. The model parameters for each lake, year, and sampling depth can be found in the Supporting Information Tables 1-3.

To test the fertilization impact on benthic GPP without the confounding factor of changing light, we looked for differences in quantum efficiency between lakes, expecting that the fertilized lakes would have greater efficiency. A one-way ANOVA showed no differences between lakes $(p=0.273)$. We also plotted average summer GPP vs. average summer ambient light levels at the sediment surface (Supporting Information Fig. 1). There is considerable scatter $\left(R^{2}=0.37\right)$ but the results show no clear impact of fertilization on average summer GPP, especially considering the pre-fertilization years may be somewhat underestimated. Core incubation temperature was not strongly or significantly correlated with either $P_{\max }(p=0.43)$, $k_{1 / 2}(p=0.42)$ or summer GPP $(p=0.982)$.

\section{Community metabolism at the whole-lake scale}

Integrating benthic GPP across all lake depths and area and normalizing to lake surface area reveals that benthic respiration exceeded benthic GPP (NEP was negative, sediments 

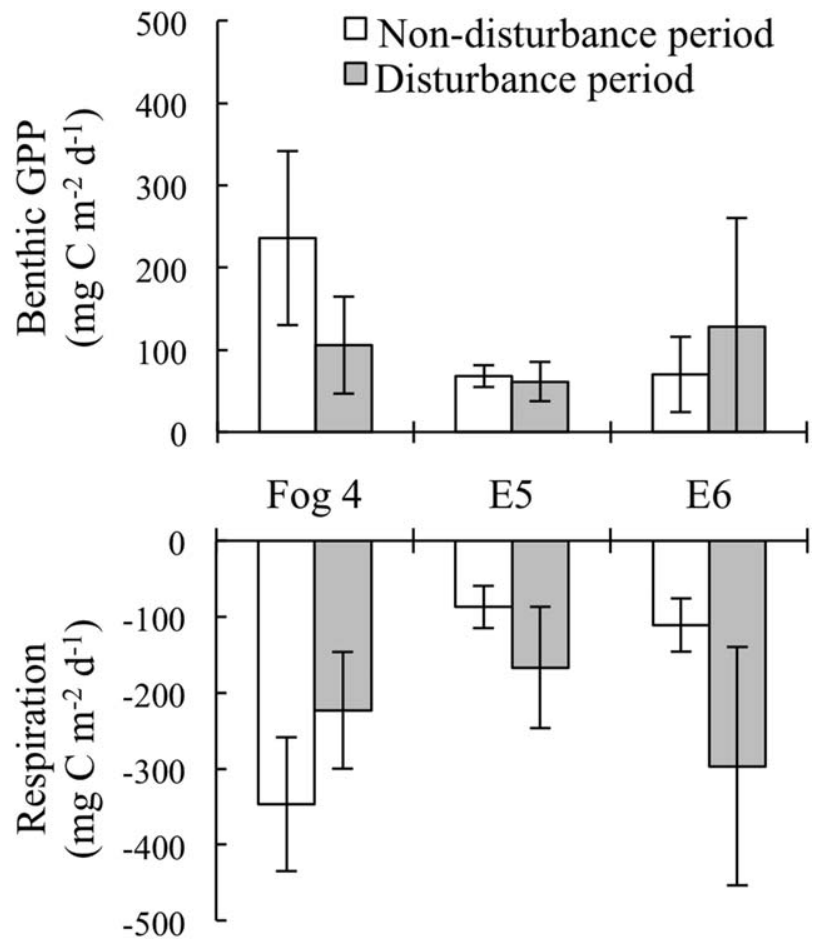

Fig. 5. Summary of disturbance impacts on benthic GPP and respiration. This combines in situ chamber measurements and core-incubation modeled GPP so does not account for the change in methodology. For thermokarst-impacted Lake Fog 4, disturbance years are 2002-2005, for the deep and shallow fertilized lakes (E5 and E6, respectively), disturbance years refers to the fertilization period 2001-2013. Only thermokarst-impacted Lake Fog 4 showed a statistically significant difference in benthic GPP $(p<0.001)$.

were net heterotrophic) in all lakes (Fig. 7). At this scale, benthic GPP was highest in the shallow fertilized lake, E6 (15 $\mathrm{g} \mathrm{C} \mathrm{m}^{-2}$ summer $^{-1}$ ), and lowest in the deep fertilized lake, E5 (4 $\mathrm{g} \mathrm{C} \mathrm{m}^{-2}$ summer $\left.^{-1}\right)$. The reference lakes were intermediate at $11 \mathrm{~g} \mathrm{C} \mathrm{m}^{-2}$ summer $^{-1}$ for the deep Lake Fog 2 and $9 \mathrm{~g} \mathrm{C} \mathrm{m}^{-2}$ summer $^{-1}$ for the shallow Lake Fog 4. Whole lake benthic NEP ranged from -12 to $-15 \mathrm{~g} \mathrm{C} \mathrm{m}^{-2}$ summer ${ }^{-1}$.

The nutrient manipulation effect on the benthic NEP lead to increased oxygen depletion in the deep stratified lake, E5. Prior to fertilization, the lowest DO concentration in E5 at any water depth was $5.96 \mathrm{mg} \mathrm{L}^{-1}$. As fertilization progressed, the hypolimnion became increasingly depleted in DO at the time of late-summer stratification. Using $8 \mathrm{~m}$ water depth as an indicator, DO declined by $0.3 \mathrm{mg} \mathrm{L}^{-1} \mathrm{yr}^{-1}$ over the $13 \mathrm{yr}$ of measurement. The first incidences of hypoxia (DO $<3 \mathrm{mg}$ $\mathrm{L}^{-1}$ ) and anoxia ( $\mathrm{DO}<0.5 \mathrm{mg} \mathrm{L}^{-1}$ ) in the bottom waters at $11 \mathrm{~m}$ depth occurred in 2008 and 2011, respectively. In contrast, there was no trend in DO concentrations over time in reference lake Fog 2 (Fig. 8), suggesting that the oxygen depletion was a response to fertilization rather than to factors independent of the fertilization. No change in summer-

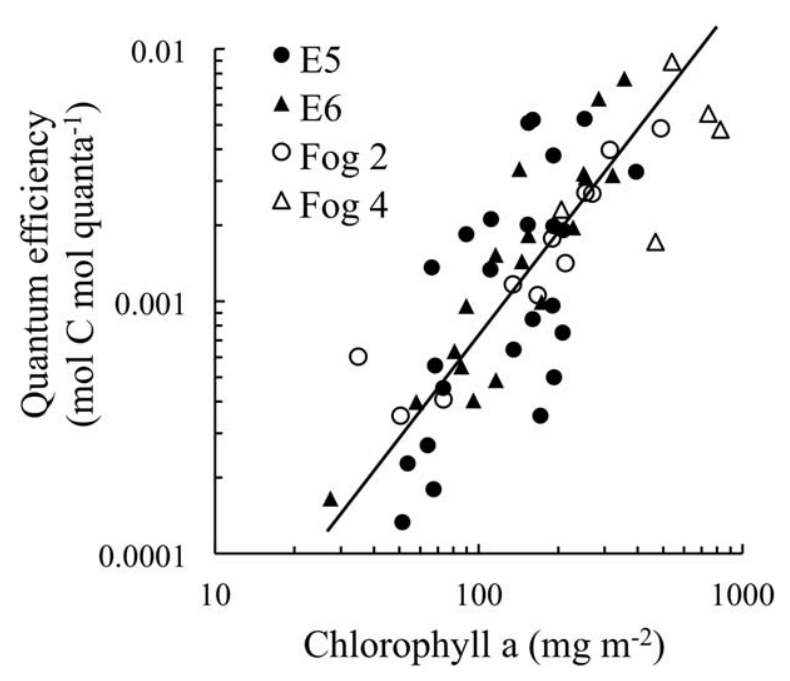

Fig. 6. Quantum efficiency determined from laboratory core incubations plotted against areal benthic $\mathrm{Chl} a$ concentration. Points represent each sampling date and depth. The line is the type II least squares regression fit for all lakes combined. The equation is $\log _{10} \mathrm{QE}=1.45 \times$ $\log _{10} \mathrm{Chl}-6.04$, where $\mathrm{QE}$ is quantum efficiency (mol $\mathrm{C}$ mol photo$\left.\mathrm{ns}^{-1}\right), \mathrm{Chl}$ is $\mathrm{Chl} a\left(\mathrm{mg} \mathrm{m}^{-2}\right)$, and the standard deviations for the slope and $y$-intercept are 0.12 and 0.27 , respectively. Lake treatments are: Fog 2-deep, reference; Fog 4-shallow, reference; E5-deep, fertilized; E6-shallow, fertilized.

time dissolved oxygen levels was evident in the shallow fertilized lake (E6) because the lake did not stratify during our monitoring.

The areal hypolimnetic oxygen deficit (AHOD) in E5 was calculated from bathymetric maps and summertime oxygen profiles for periods when thermal stratification was stable. The AHOD was between $203 \mathrm{mg} \mathrm{O}_{2} \mathrm{~m}^{-2} \mathrm{~d}^{-1}$ and $664 \mathrm{mg} \mathrm{O}_{2}$ $\mathrm{m}^{-2} \mathrm{~d}^{-1}$ and increased by $15 \mathrm{mg} \mathrm{O}_{2} \mathrm{~m}^{-2} \mathrm{~d}^{-1}$ per year during the $13 \mathrm{yr}$ of monitoring $\left(R^{2}=0.34, p=0.042\right.$; Fig. 9a). The AHOD of Lake E5 is positively, but not statistically, correlated with the estimated NEP of the benthic community at $6 \mathrm{~m}$ depth $\left(R^{2}=0.26, p=0.16\right.$; Fig. $\left.9 \mathrm{~b}\right)$. Water column sampling of the deep reference lake Fog 2 lacked the temporal resolution necessary to calculate AHOD with confidence.

\section{Discussion}

We performed whole-lake nutrient enrichment experiments to test the relative importance of nutrients and light as limiting factors to benthic primary production in Arctic lakes. Our results support several previous studies which demonstrate that water clarity and lake morphometry are important regulators of benthic GPP at the whole-lake scale (Liboriussen and Jeppesen 2003; Vadeboncoeur et al. 2008; Whalen et al. 2008). Our results also suggest that (1) slight nutrient enrichment did not stimulate benthic algae regardless of lake shape, (2) variation in PAR is an important control on benthic GPP in the study lakes and the effect of fertilization on water column light attenuation was greater 
Table 2. Background and fertilized rates of annual $P$ and $N$ loading ( $\mathrm{mg} \mathrm{m}^{-3} \mathrm{yr}^{-1}$ ) to the lake surface mixed layer (equivalent to the whole lake for shallow systems). Values from other whole-lake manipulations are either as reported or converted to a volumetric basis $\left(\mathrm{m}^{-3}\right)$ from an areal basis $\left(\mathrm{m}^{-2}\right)$ by dividing by the mean depth of the lake or mixed layer where appropriate and scaled to the annual addition rates.

\begin{tabular}{|c|c|c|c|c|c|}
\hline & E6 & & 8 & & 56 \\
\hline O'Brien et al. (2005) & N2 & & $75-91$ & & $426-535$ \\
\hline \multirow[t]{2}{*}{ Vadeboncoeur et al. (2001) } & Peter & 105 & $41-122$ & & \\
\hline & West Long & 105 & $42-150$ & & \\
\hline Björk-Ramberg and Ånell (1985) & Hymenjaure & & $75-258$ & & 3216 \\
\hline \multirow[t]{3}{*}{ Bergmann and Welch (1990) } & Spring & 88 & 0 & 175 & 0 \\
\hline & Far & 108 & 25 & 145 & 0 \\
\hline & $P \& N$ & 82 & 25 & 115 & 290 \\
\hline
\end{tabular}

in the deep lake than in the shallow lake, and (3) low-level nutrient enrichment can drive an increase in AHOD by increasing benthic respiration and decreasing benthic NEP.

\section{Benthic algae response to nutrient addition}

Previous experiments in Arctic and sub-Arctic lakes have tested the response of benthic microalgae to nutrient additions. From shallow ponds $\left(z_{\max }=0.2 \mathrm{~m}\right)$ near Barrow, Alaska, Stanley (1976) observed a doubling of benthic GPP from 540 to $1080 \mathrm{mg} \mathrm{C} \mathrm{m}^{-2} \mathrm{~d}^{-1}$ with the addition of phosphorus. Likewise, $\mathrm{N}$ and $\mathrm{P}$ addition stimulated benthic chlorophyll (but not GPP) in shallow Lake Hymenjaure $\left(z_{\max }=3.4 \mathrm{~m}\right)$ in Sweden (Björk-Ramberg and Ånell 1985). However, in the majority of whole-lake enrichment experiments, especially those in lakes that we would classify as

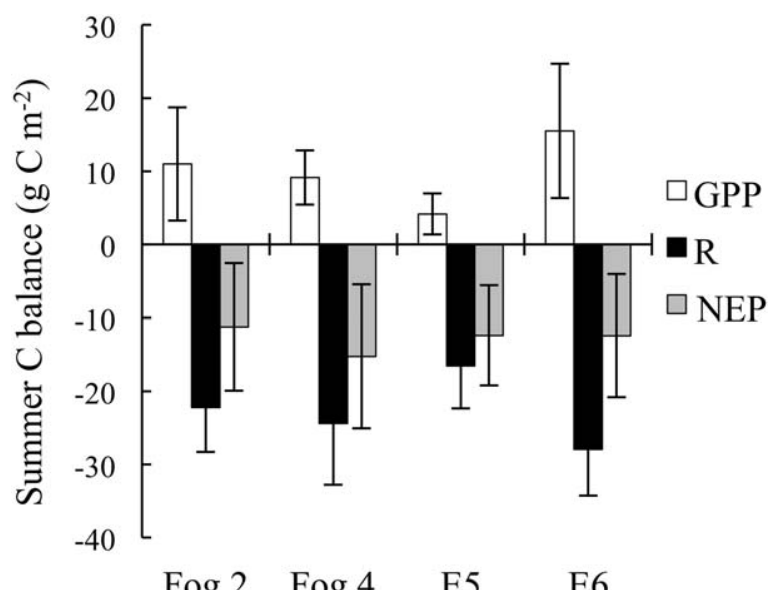

Fog 2 Fog $4 \quad$ E5 E6

Fig. 7. GPP, $\mathrm{R}$, and $\operatorname{NEP}\left(\mathrm{g} \mathrm{C} \mathrm{m}^{-2}\right.$ summer $\left.^{-1}\right)$ calculated at the wholelake scale and summed from June 15 to August 31. Lake treatments are: Fog 2-deep, reference; Fog 4-shallow, reference; E5-deep, fertilized; E6-shallow, fertilized. deep enough to routinely stratify, there was no such response by benthic algae, and in many cases, benthic GPP was suppressed due to lower light conditions upon fertilization (Vadeboncoeur et al. 2001). As such, benthic microalgae are generally considered light, rather than nutrient limited.

Light seems to be the limiting resource for benthic algae in our study lakes, despite the low water column nutrient concentrations. This is exemplified at two scales in our study. First, the interactions of lake depth and water quality interact to affect available light, and by extension benthic GPP, at the whole-lake scale. Specifically, even though the clear and deep reference lake (Fog 2) had similar benthic $P_{\max }$ and $k_{1 / 2}$ values as did the DOC-rich lake of similar morphometry (E5), it had $\sim 250 \%$ higher summer benthic GPP

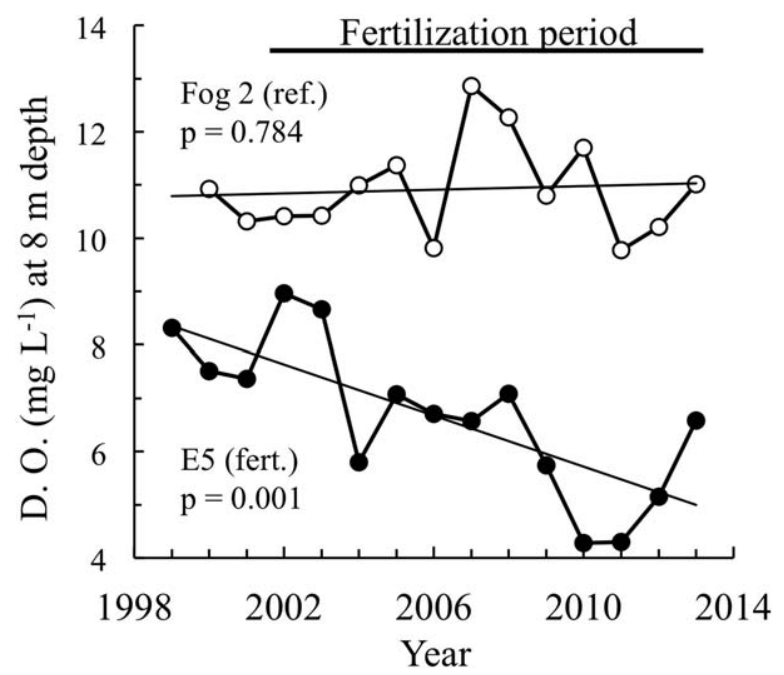

Fig. 8. Summer (JJA) average dissolved oxygen concentrations measured at $8 \mathrm{~m}$ depth in the two deep stratified lakes. Horizontal bar as in previous figures. 

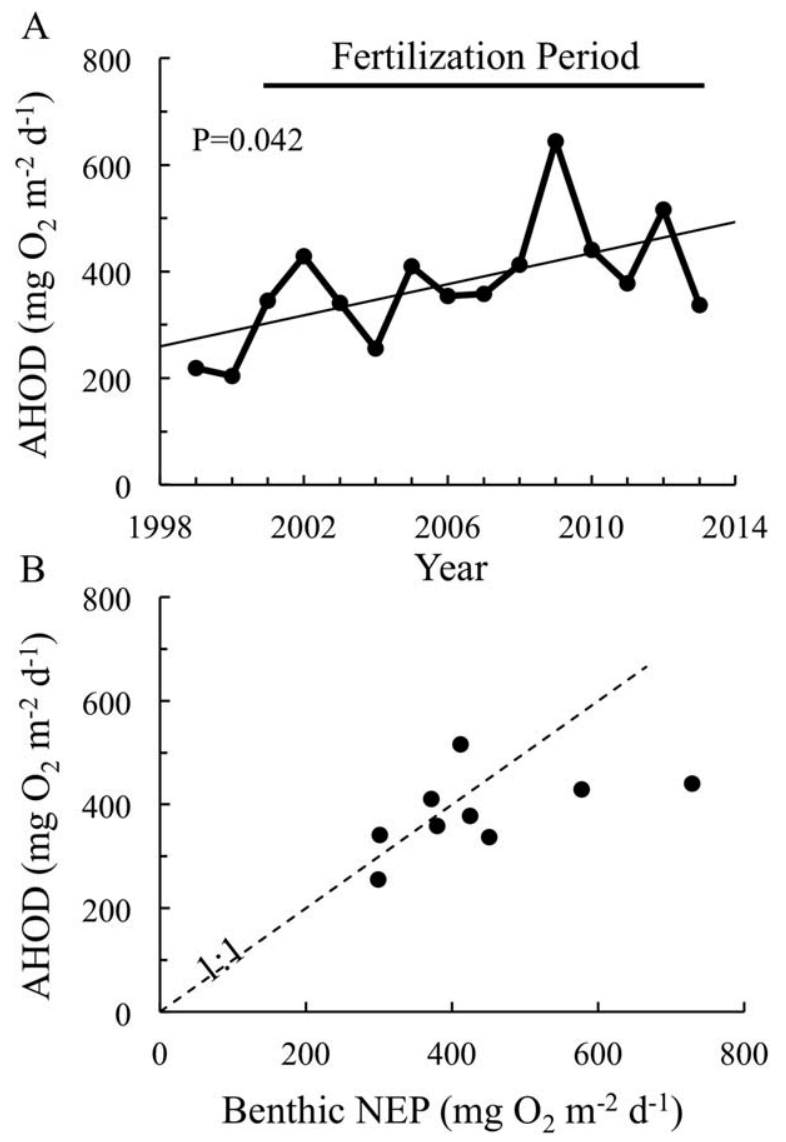

Fig. 9. (A) Summertime areal hypolimnetic oxygen deficit in Lake E5, with the fertilization period represented by the horizontal bar. (B) Lake E5 AHOD vs. benthic net ecosystem production determined from our hypolimnion sampling stations.

on an areal basis because light penetrated to sediment deeper in the lake. Likewise, the shallow lakes, E6 and Fog 4, had $370 \%$ and $220 \%$ higher productivity on an areal basis than did Lake E5 at the whole-lake scale, despite similar water column light attenuation properties. Second, nutrient addition did not stimulate benthic GPP at the depth-specific scale. While the increase in benthic Chl $a$ in the first $3 \mathrm{yr}$ of fertilization in both Lake E5 and E6 suggested a positive response of benthic algae to fertilization (Gettel et al. 2013), during the 13-yr fertilization period, benthic Chl a returned to pre-fertilization levels. This, together with the observations that (1) there was no difference in quantum efficiency between the fertilized and reference lakes, (2) no obvious change in the relationship between GPP and ambient PAR from pre- to post-fertilization (Supporting Information Fig. 1), and (3) GPP did not increase significantly during the course of the experiment in either fertilized lake, indicates that the nutrient addition did not positively impact benthic algae.

The prevalence of light limitation is further supported by nutrient addition experiments performed on individual cores incubated under saturating light conditions by Gettel et al. (2013). They added N, P, or N plus P to the overlying water of cores from Lake Fog 2 and observed no response in terms of GPP or Chl $a$ over periods up to $9 \mathrm{~d}$. A similar finding, in terms of benthic pigments, was found in Ward Hunt Lake in Canada by Bonilla et al. (2005). While the turnover time of benthic algae is on the order of 2 months to years in highlatitude lakes (Björk-Ramberg and Ånell 1985), longer than the 9-d incubations, our time series of $13 \mathrm{yr}$ should be sufficiently long to capture potential nutrient stimulation effects.

Our measured lack of benthic stimulation to nutrients may have been different in the epilithon of the rocky littoral area because epilithon do not have access to sediment porewater nutrients and because they receive more light (Vadeboncoeur et al. 2001). The rocky littoral zone, however, comprises a relatively small proportion of each lake study and thus is unlikely to impact the overall benthic GPP at the whole-lake scale.

The concentrations of benthic Chl $a$ we observed are quite high compared to benthic mats, epilithon, and epipelon measured in other polar freshwaters (Quesada et al. 2008; Bowden et al. 2014), but are not unprecedented. Whalen et al. (2008) measured benthic Chl $a$ concentrations of 258$699 \mathrm{mg} \mathrm{m}^{-2}$ in the top $2 \mathrm{~cm}$ of sediment in Alaska tundra lakes, which were two orders of magnitude greater than the areal phytoplankton Chl $a$. We also measured Chl $a$ in the surface $2 \mathrm{~cm}$ of sediment. The positive correlation between benthic Chl $a$ and quantum efficiency suggests that Chl $a$ over this sediment depth is a reasonable parameter for estimating community photosynthetic potential, although we expect the relationship in Fig. 6 would have been stronger had we sampled a thinner layer of sediment because only algae residing in the sediment photic zone (1-4 mm) can actively photosynthesize at a given time (MacIntyre and Cullen 1995). Regardless, one would expect an increase in benthic Chl $a$ concentrations during the experiment if $\mathrm{N}$ and $\mathrm{P}$ from the overlying water column were limiting benthic algae growth. Because benthic Chl $a$ was not higher in a sustained way in either lake, we conclude that these benthic algae were not limited by $\mathrm{N}$ or $\mathrm{P}$ during the summers.

\section{Regulation of light}

Because light is commonly limiting for benthic algae production (Vadeboncoeur et al. 2001), understanding the fertilization impact on light attenuation is an important aspect of this study. High concentrations of DOC, and especially the fraction of colored dissolved organic matter (CDOM), and lake morphology can interact to modulate the impact of nutrient addition on light availability to benthic algae. To our knowledge, our study is the first to assess the dynamic, long-term response of benthic algae in high-DOC, low-chlorophyll lakes (Table 1) during low-level nutrient enrichment (Table 2). This scenario may typify the trajectory of boreal lakes and some Arctic lakes (Tranvik et al. 2009; Rautio et al. 
Table 3. Pre-disturbance and post-disturbance estimates of the epipelic community characteristics (average (SE) for chlorophyll; average (SD) for GPP and R; NEP calculated as sum of GPP and R with a combined SD). Pre-fertilization values are from chamber measurements while post-fertilization values are from a combination of chamber and core measurements. For Lake Fog 2, there was no fertilization treatment, but years were divided to match the experimental lakes. For Lake Fog 4, TK and NTK refer to the periods with an observed thermokarst-related sediment plume, and periods with no sediment plume, respectively.

\begin{tabular}{|c|c|c|c|c|c|c|c|c|}
\hline & Pre-fert & Post-fert & Pre-fert & Post-fert & Pre-fert & Post-fert & Pre-fert & Post-fert \\
\hline \multicolumn{9}{|l|}{ Fog 2} \\
\hline $3.5 \mathrm{~m}$ & $100(48)$ & $150(23)$ & 110 & $175(142)$ & -142 & $-220(105)$ & -32 & $-45(176)$ \\
\hline $6 \mathrm{~m}$ & $351(54)$ & $303(29)$ & & $197(148)$ & & $-256(206)$ & & $-59(253)$ \\
\hline $6 \mathrm{~m}$ & $66(26)$ & $121(12)$ & & $8(57)$ & & $-185(94)$ & & $-177(110)$ \\
\hline \multicolumn{9}{|l|}{ E6 } \\
\hline \multirow[t]{2}{*}{$2 \mathrm{~m}$} & $126(13)$ & $210(12)$ & $62(40)$ & $128(132)$ & $-111(35)$ & $-297(157)$ & $-49(21)$ & $-169(205)$ \\
\hline & NTK & TK & NTK & TK & NTK & TK & NTK & TK \\
\hline \multicolumn{9}{|l|}{ Fog 4} \\
\hline
\end{tabular}

2011) in a warmer and more nitrogen-rich world (Prowse et al. 2006; Elser et al. 2009; Hobbs et al. 2010).

In this study, the fertilization experiments had a higher impact on light extinction coefficients in the deep lake (E5) than in the shallow lake (E6). This different response suggests a morphological control on the impact of low-level enrichment. The difference derives from lower stimulation of phytoplankton biomass, on a volumetric basis, observed in Lake E6. In the absence of a strong benthic algal response, we hypothesize that high abiotic nutrient sequestration by lake sediments contributes to the weak phytoplankton response in Lake E6. This explanation is plausible considering the affinity for phosphorus to complex with the iron-rich lake sediments (Cornwell and Kipphut 1992) and the potentially rapid transfer of phosphorus to the sediments in a shallow setting. Genkai-Kato et al. (2012) proposed that at nutrient loading rates above 2-5 mg $\mathrm{P} \mathrm{m}^{-2} \mathrm{~d}^{-1}$, lakes could alternate from a clear to a turbid stable state. We did not observe such a transition in Lake E6 despite our experimental loading rates of $16 \mathrm{mg} \mathrm{m}^{-2} \mathrm{~d}^{-1}$. The threshold for stable-state transition may therefore be somewhat higher in these experimental lakes due to the abiotic P absorption capacity of the sediments. In the deeper Lake E5, we suggest that added nutrients had less contact with the sediments, allowing for greater recycling within the water column, thereby having a stronger effect on phytoplankton biomass than in the shallow lake.

The similar temporal variation of light attenuation and benthic GPP in the non-thermokarst lakes suggests a regional influence on the light environment and benthic processes. The amount of light absorbed in these lakes by CDOM is related strongly to DOC concentrations (e.g., Cory et al. 2014; ARC LTER database), and because summer average DOC concentrations were correlated between lakes (ARC LTER database), a regional control on DOC inputs may explain the temporal patterns in light attenuation. The export of DOC from land to surface waters is dependent on water flow, and by extension, spring melting and precipitation events (Judd and Kling 2002), and thus it is not surprising that light attenuation would vary synchronously across nearby lakes. Factors that regulate DOC in Arctic lakes on seasonal and interannual timescales no doubt play an important role on the annual benthic GPP. Our experiment was meant to mimic slight changes to nutrient loading that may result from warming climate. However, excess nutrients that stem from increased flushing of soils are likely to be accompanied by additional allochthonous DOC (Prowse et al. 2006; Sobek et al. 2007; Kling et al. 2014). Thus, stimulated phytoplankton biomass and greater DOC delivery can work in tandem to reduce the light available to benthic algae.

\section{Benthic respiration and dissolved oxygen}

Benthic respiration exceeded gross primary production in nearly all lakes, years, and sampling depths in our study. This is a common, but not universal (Ask et al. 2009), trait of lake benthos and contributes to the net heterotrophic nature of most lakes worldwide (Cole et al. 2000). In the Arctic, benthic communities are important for oxygen consumption in lakes (Miller and Reed 1975; Jonsson et al. 2003; Lienesch et al. 2005), although the oligotrophic status of most Arctic lakes usually prevents development of hypoxia or anoxia.

Dissolved oxygen depletion is a well-established sign and symptom of nutrient enrichment (Wetzel 2001 and 
references therein). In two enrichment experiments using high nutrient levels in lakes near Toolik Lake, anoxia was induced after just $3 \mathrm{yr}$ of fertilization (Lake N2; O'Brien et al. 2005) and 2 yr of fertilization (Lake N1; Lienesch et al. 2005). In the second experiment, anoxia near the sedimentwater interface lead to reduced survivorship of fish eggs and reduced recruitment of lake trout during the fertilization period (Lienesch et al. 2005). The AHOD of Lake E5 is comparable to other oligotrophic to mesotrophic lakes (e.g., Wetzel 2001) but less severe than the oxygen depletion from other nearby Arctic experimental lakes (O'Brien et al. 2005). The difference in severity probably stems from the lowerlevel of nutrient addition employed in our study.

The strong oxygen depletion observed in Lake E5 was not observed in the reference lake and was accompanied by a decline in benthic NEP over time due to the steady increase in benthic respiration. It is extremely difficult to separate benthic respiration into autotrophic and heterotrophic components. Because autotrophic respiration is proportional to GPP, and GPP did not increase, we assume that heterotrophic activity must be the cause of the increased respiration. It is probable that this increase in respiration in the deep fertilized lake, E5, was due to greater flux of phytoplankton to the sediments. In E5, pelagic NPP rates increased sixfold between the pre- and post-fertilization periods (pre-fertilization NPP $18 \pm 10 \mathrm{mg} \mathrm{C} \mathrm{m}^{-2} \mathrm{~d}^{-1}$ vs. post-fertilization average of $108 \pm 30 \mathrm{mg} \mathrm{C} \mathrm{m}^{-2} \mathrm{~d}^{-1}$ for 2001-2009; M. Evans, G. Kling unpubl. data). This equates to an extra $\sim 90 \mathrm{mg} \mathrm{C} \mathrm{m}^{-2} \mathrm{~d}^{-1}$, compared to an increase in benthic respiration of $80 \mathrm{mg} \mathrm{C}$ $\mathrm{m}^{-2} \mathrm{~d}^{-1}$. While some fraction of the extra pelagic production is respired in the water column, the similarity in these values suggests that increased phytoplankton deposition can account for the majority of the increase in benthic respiration in E5.

There is less potential for significant oxygen depletion in the bottom of Lake E6 compared to Lake E5 because bottom waters are more frequently equilibrated with the atmosphere through wind-driven mixing of the water column. The benthic data from Lake E6 hint at increases in both benthic GPP and respiration (Fig. 5), resulting in little change in benthic NEP. In Lake E5 settling phytoplankton likely contributed to decreasing benthic NEP during the experiment. This effect was smaller in shallow Lake E6 where pelagic NPP only increased by $\sim 41 \mathrm{mg} \mathrm{C} \mathrm{m}{ }^{-2} \mathrm{~d}^{-1}$ (pre-fertilization NPP $38 \pm 24 \mathrm{mg} \mathrm{C} \mathrm{m}^{-2} \mathrm{~d}^{-1}$ in 2000 , vs. post-fertilization average of $79 \pm 29 \mathrm{mg} \mathrm{C} \mathrm{m}^{-2} \mathrm{~d}^{-1}$ for 2001-2009; M. Evans, G. Kling unpubl. data) and pelagic Chl $a$ was unchanged. This difference may result from the different area-based fertilization rates among the experimental lakes (E5 received higher $\mathrm{N}$ and P loading on an area-basis than E6, even though volumetric loading was the same), which could have produced a higher depth-integrated phytoplankton response. Because pelagic Chl $a$ did not increase on a volumetric-basis in Lake E6, however, this explanation is less likely.

\section{Thermokarst failure}

The frequency of thermokarst failures is thought to be increasing in the Arctic (Rowland et al. 2010). When active layer detachments or retrogressive thaw slumps occur adjacent to lakes, they have the potential to radically alter lake ecosystem processes. The lifespan of these disturbance events is generally on the order of $1-5 \mathrm{yr}$ of active release of nutrients and sediment into surface waters (Bowden et al. 2008), and the impact can vary in severity.

In terms of benthic processes, it is thought that clastic sediment released from thermokarst failures initially has a smothering effect on benthic algae, effectively burying the benthic community and suppressing photosynthesis (C. Johnson unpubl. data). Additionally, during the period of active sediment delivery from these features, water clarity is likely to be reduced because of greater suspended solids. This was observed in Lake Fog 4 as an increase in light attenuation coefficients from 2002 to 2005 that lowered light available at the sediments by $53 \%$ at $2 \mathrm{~m}$ depth, and lowered GPP by $120 \mathrm{mg} \mathrm{C} \mathrm{m}^{-2} \mathrm{~d}^{-1}$, or $\sim 55 \%$. This decrease is considerably greater than the decrease driven by our low-level fertilization in Lake E5. Mesquita et al. (2010) reported that suspended clay particles delivered during a thermokarst failure are effective at adsorbing and removing CDOM from lakes, resulting in a clarifying effect upon settling, which would benefit the benthic algae. In Lake Fog 4 light attenuation recovered to, but not below, pre-thermokarst values, which we suggest is due to a combination of low initial DOC concentration (less potential for a clarifying effect) and active resuspension of sediments. As such, one must consider initial lake properties when predicting shoreline disturbance impacts on lake light attenuation and benthic productivity response.

Benthic changes in the thermokarst-impacted Fog 4 differed from the experimental $\mathrm{N}$ and $\mathrm{P}$ manipulation lakes. GPP and respiration both decreased, while benthic chlorophyll increased to the highest values observed in any lake. The decrease in respiration is consistent with the smothering effect by clastic deposition. While we did not do textural analysis of the thermokarst-sourced material, we postulate that dilution of organic matter by clay and silt, and capping of the active surface sediments, would have lowered the rates of both autotrophic and heterotrophic respiration. It is difficult to ascertain whether this conclusion is consistent with the large increase in Chl $a$ concentration. An explanation for such high Chl $a$ concentrations could be that as sediment rapidly accumulated during the summers of thermokarst activity, the surface layer was constantly colonized by algae, resulting in a relatively deep layer of active chlorophyll-containing sediments. This scenario would explain why Lake Fog 4 sediments fall below the regression line in Fig. 6-only the surface-most sediments contribute to the observed $P_{\max }$ and quantum efficiency observed in the core incubations, because light is typically absent below 
millimeters of the sediment surface (Stanley 1976; MacIntyre and Cullen 1995); therefore, despite high Chl $a$ concentrations over $2 \mathrm{~cm}$, the photosynthesis parameters were not especially high.

\section{Conclusion}

Our results indicate that rates of benthic GPP of our study lakes did not respond to low-level nutrient addition, despite the extremely oligotrophic nature of the lakes. Instead, light seems to limit benthic algae productivity, even for sediments in the shallow littoral zone. Changes in light attenuation caused by variations in DOC appear correlated between lakes and can possibly be linked to meteorological controls. Changes in light attenuation due to fertilization were different in the two experimental lakes, with an effect on water column properties only evident in the deep, stratified lake. Likewise, benthic respiration was impacted by the addition of nutrients only in the deep, stratified lake. Lake morphology may therefore play an important role in the fate of nutrients and subsequent impact on benthic processes. If our low-level fertilization regime realistically simulates future changes in nutrient loading to deep Arctic lakes, then hypoxia driven by benthic respiration could become a more common feature of those lakes. The importance of light is also illustrated by our observations in a shallow lake that experienced a shoreline thermokarst failure. In this case, elevated nutrients and sediment inputs and deposition worked in tandem to increase water-column light attenuation and substantially decrease benthic GPP during the period of active sediment delivery.

\section{References}

ARC LTER database. Available from http://ecosystems.mbl. edu/ARC/datacatalog.html. Accessed January 25, 2013.

Ask, J., J. Karlsson, L. Persson, P. Ask, P. Byström, and M. Jansson. 2009. Whole-lake estimates of carbon flux through algae and bacteria in benthic and pelagic habitats of clearwater lakes. Ecology 90: 1923-1932. doi:10.1890/07-1855.1

Bender, M., and others. 1987. A comparison of four methods for determining planktonic community production. Limnol. Oceanogr. 32: 1085-1098. doi:10.4319/lo.1987.32.5.1085

Bergmann, M. A., and H. E. Welch. 1990. Nitrogen fixation by epilithic periphyton in small arctic lakes in response to experimental nitrogen and phosphorus fertilization. Can. J. Fish. Aquat. Sci. 47: 1545-1550. doi:10.1139/f90-174

Bettez, N. D., P. A. Rublee, J. O'Brien, and M. C. Miller. 2002. Changes in abundance, composition and controls within the plankton of a fertilised arctic lake. Freshw. Biol. 47: 303-311. doi:10.1046/j.1365-2427.2002.00806.x

Björk-Ramberg, S., and C. Ånell. 1985. Production and chlorophyll concentration of epipelic and epilithic algae in fertilized and nonfertilized subarctic lakes. Hydrobiologia 126: 213-219. doi: $10.1007 / \mathrm{BF} 00007498$
Bonilla, S., V. Villeneuve, and W. F. Vincent. 2005. Benthic and planktonic algal communities in a high Arctic lake: Pigment structure and contrasting responses to nutrient enrichment. J. Phycol. 41: 1120-1130. doi:10.1111/ j.1529-8817.2005.00154.x

Bowden, W. B., M. N. Gooseff, A. Balser, A. Green, B. J. Peterson, and J. Bradford. 2008. Sediment and nutrient delivery from thermokarst features in the foothills of the North Slope, Alaska: Potential impacts on headwater stream ecosystems. J. Geophys. Res. 113: G02026. doi: 10.1029/2007JG000470

Bowden, W. B., and others. 2014. Ecology of streams of the Toolik Region, p. 173-237. In J. E. Hobbie and G. W. Kling [eds.], Alaska's changing Arctic: Ecological consequences for tundra, streams, and lakes. Oxford Univ. Press.

Cherry, J. E., S. J. Déry, M. Stieglitz, and F. Pan. 2014. Meteorology and climate of Toolik Lake and the north slope of Alaska: Past, present and future, p. 143-172. In J. E. Hobbie and G. W. Kling [eds.], Alaska's changing Arctic: Ecological consequences for tundra, streams, and lakes. Oxford Univ. Press.

Cole, J. J., M. L. Pace, S. R. Carpenter, and J. F. Kitchell. 2000. Persistence of net heterotrophy in lakes during nutrient addition and food web manipulations. Limnol. Oceanogr. 45: 1718-1730. doi:10.4319/lo.2000.45.8.1718

Cornwell, J., and G. Kipphut. 1992. Biogeochemistry of manganese- and iron-rich sediments in Toolik Lake, Alaska. Hydrobiologia 240: 45-59. doi:10.1007/BF00013451

Cory, R. M., C. P. Ward, B. C. Crump, and G. W. Kling. 2014. Sunlight controls water column processing of carbon in arctic fresh waters. Science 345: 925-928. doi: 10.1126/science. 1253119

Elser, J. J., and others. 2009. Shifts in lake N:P stoichiometry and nutrient limitation driven by atmospheric nitrogen deposition. Science 326: 835-837. doi:10.1126/ science. 1176199

Fee, E. J. 1979. A relation between lake morphometry and primary productivity and its use in interpreting wholelake eutrophication experiments. Limnol. Oceanogr. 24: 401-416. doi:10.4319/1o.1979.24.3.0401

Genkai-Kato, M., Y. Vadeboncoeur, L. Liboriussen, and E. Jeppesen. 2012. Benthic-planktonic coupling, regime shifts, and whole-lake primary production in shallow lakes. Ecology 93: 619-631. doi:10.1890/10-2126.1

Gettel, G. M., A. E. Giblin, and R. W. Howarth. 2013. Controls of benthic nitrogen fixation and primary production from nutrient enrichment of oligotrophic, Arctic lakes. Ecosystems 16: 1550-1564. doi:10.1007/s10021-013-9701-0

Hansson, L.-A. 1992. Factors regulating periphytic algal biomass. Limnol. Oceanogr. 37: 322-328. doi:10.4319/ 10.1992.37.2.0322

Hershey, A. E. 1992. Effects of experimental fertilization on the benthic macroinvertebrate community of an arctic 
lake. J. N. Am. Benthol. Soc. 11: 204-217. doi:10.2307/ 1467386

Hobbie, J. E., B. J. Peterson, N. Bettez, and others. 1999. Impact of global change on the biogeochemistry and ecology of an Arctic freshwater system. Polar Res. 18: 207214. doi:10.1111/j.1751-8369.1999.tb00295.x

Hobbs, W. O., R. J. Telford, H. J. B. Birks, J. E. Saros, R. R. O. Hazewinkel, B. B. Perren, E. Saulnier-Talbot, and A. P. Wolfe. 2010. Quantifying recent ecological changes in remote lakes of North America and Greenland using sediment diatom assemblages. PLoS ONE 5: e10026. doi: 10.1371/journal.pone.0010026

Hobson, K. A., and H. E. Welch. 1995. Cannibalism and trophic structure in a high Arctic lake: Insights from stable-isotope analysis. Can. J. Fish. Aquat. Sci. 52: 11951201. doi:10.1139/f95-116

Howarth, R. W. 1988. Nutrient limitation of net primary production in marine ecosystems. Annu. Rev. Ecol. Syst. 19: 89-110. doi:10.1146/annurev.ecolsys.19.1.89

Jäger, C. G. and S. Diehl. 2014. Resource competition across habitat boundaries: Asymmetric interactions between benthic and pelagic producers. Ecol. Monogr. 84: 287-302. doi:10.1890/13-0613.1

Jonsson, A., J. Karlsson, and M. Jansson. 2003. Sources of carbon dioxide supersaturation in clearwater and humic lakes in northern Sweden. Ecosystems 6: 224-235. doi: 10.1007/s10021-002-0200-y

Judd, K. E., and G. W. Kling. 2002. Production and export of dissolved $\mathrm{C}$ in arctic tundra mesocosms: The roles of vegetation and water flow. Biogeochemistry 60: 213-234. doi: 10.1023/A:1020371412061

Karlsson, J., P. Byström, J. Ask, P. Ask, L. Persson, and M. Jansson. 2009. Light limitation of nutrient-poor lake ecosystems. Nature 460: 506-509. doi:10.1038/nature08179

Kling, G. W., and others. 2014. Land-water interactions, p. 143-172. In J. E. Hobbie and G. W. Kling [eds.], Alaska's changing Arctic: Ecological consequences for tundra, streams, and lakes. Oxford Univ. Press.

Liboriussen, L., and E. Jeppesen. 2003. Temporal dynamics in epipelic, pelagic and epiphytic algal production in a clear and a turbid shallow lake. Freshw. Biol. 48: 418-431. doi:10.1046/j.1365-2427.2003.01018.x

Lienesch, P. W., M. E. McDonald., A. E. Hershey, W. J. O'Brien, and N. D. Bettez. 2005. Effects of a whole-lake, experimental fertilization on lake trout in a small oligotrophic arctic lake. Hydrobiologia 548: 51-66. doi: 10.1007/s10750-005-3620-9

Lorenzen, C. J. 1967. Determination of chlorophyll and pheo-pigments: Spectrophotometric equations. Limnol. Oceanogr. 12: 343-346. doi:10.4319/1o.1967.12.2.0343

MacIntyre, H. L., and J. J. Cullen. 1995. Fine-scale vertical resolution of chlorophyll and photosynthetic parameters in shallow-water benthos. Mar. Ecol. Prog. Ser. 122: 227237. doi:10.3354/meps 122227
MacIntyre, S., J. P. Fram, P. J. Kushner, N. D. Bettez, W. J. O'Brien, J. Hobbie, and G. W. Kling. 2009. Climaterelated variations in mixing dynamics in an Alaskan arctic lake. Limnol. Oceanogr. 54: 2401-2417. doi:10.4319/ lo.2009.54.6_part_2.2401

Mesquita, P. S., F. J. Wrona, and T. D. Prowse. 2010. Effects of retrogressive permafrost thaw slumping on sediment chemistry and submerged macrophytes in Arctic tundra lakes. Freshw. Biol. 55: 2347-2358. doi:10.1111/j.13652427.2010.02450.x

Miller, M., and J. Reed. 1975. Benthic metabolism of arctic coastal ponds, Barrow, Alaska. Verh. Intern. Verein. Limnol. 19: 459-465.

Morris, D. P., and W. M. Lewis. 1988. Phytoplankton nutrient limitation in Colorado mountain lakes. Freshw. Biol. 20: 315-327. doi:10.1111/j.1365-2427.1988.tb00457.x

Nolen, S. L., J. Wilhm, and G. Howick. 1985. Factors influencing inorganic turbidity in a great plains reservoir. Hydrobiologia 123: 109-117. doi:10.1007/BF00018973

O'Brien, W. J., and others. 2005. Long-term response and recovery to nutrient addition of a partitioned arctic lake. Freshw. Biol. 50: 731-741. doi:10.1111/j.13652427.2005.01354.X

Prowse, T. D., F. J. Wrona, J. D. Reist, J. J. Gibson, J. E. Hobbie, L. M. J. Lévesque, and W. F. Vincent. 2006. Climate change effects on hydroecology of Arctic freshwater ecosystems. AMBIO J Hum. Environ. 35: 347-358. doi: 10.1579/0044-7447(2006)35[347:CCEOHO]2.0.CO;2

Quesada, A., E. Fernandez-Valiente, I. Hawes, C. HowardWilliams, and W. F. Vincent. 2008. Benthic primary production in polar lakes and rivers. Oxford Univ. Press.

Rautio, M., F. Dufresne, I. Laurion, S. Bonilla, W. F. Vincent, and K. S. Christoffersen. 2011. Shallow freshwater ecosystems of the circumpolar Arctic. Ecoscience 18: 204-222. doi:10.2980/18-3-3463

Rowland, J., and others. 2010. Arctic landscapes in transition: Responses to thawing permafrost. Trans. Am. Geophys. Union 91: 229-230. doi:10.1029/2010EO260001

Schindler, D. 1978. Factors regulating phytoplankton production and standing crop in the world's freshwaters. Limnol. Oceanogr. 23: 478-486. doi:10.4319/1o.1978.23.3.0478

Sobek, S., L. J. Tranvik, Y. T. Prairie, P. Kortelainen, and J. J. Cole. 2007. Patterns and regulation of dissolved organic carbon: An analysis of 7,500 widely distributed lakes. Limnol. Oceanogr. 52: 1208-1219. doi:10.4319/lo.2007.52.3.1208

Stanley, D. W. 1976. Productivity of epipelic algae in tundra ponds and a lake near Barrow, Alaska. Ecology 57: 10151024. doi:10.2307/1941066

Tranvik, L. J. and others. 2009. Lakes and reservoirs as regulators of carbon cycling and climate. Limnol. Oceanogr. 54: 2298-2314. doi:10.4319/1o.2009.54.6_part_2.2298

Vadeboncoeur, Y., E. Jeppesen, M. J. Vander Zanden, H.-H. Schierup, K. Christoffersen, and D. M. Lodge. 2003. From Greenland to green lakes: Cultural eutrophication and the 
loss of benthic pathways in lakes. Limnol. Oceanogr. 48: 1408-1418. doi:10.4319/1o.2003.48.4.1408

Vadeboncoeur, Y., D. M. Lodge, and S. R. Carpenter. 2001. Whole-lake fertilization effects on distribution of primary production between benthic and pelagic habitats. Ecology 82: 1065-1077. doi:10.1890/0012-9658(2001)082[1065: WLFEOD]2.0.CO;2

Vadeboncoeur, Y., G. Peterson, M. J. Vander Zanden, and J. Kalff. 2008. Benthic algal production across lake size gradients: Interactions among morphometry, nutrients, and light. Ecology 89: 2542-2552. doi:10.1890/07-1058.1

Vadeboncoeur, Y., and A. D. Steinman. 2002. Periphyton function in lake ecosystems. Sci. World J. 2: 1449-1468. doi:10.1100/tsw.2002.294

Vähätalo, A. V., M. Salkinoja-Salonen, P. Taalas, and K. Salonen. 2000. Spectrum of the quantum yield for photochemical mineralization of dissolved organic carbon in a humic lake. Limnol. Oceanogr. 45: 664-676. doi:10.4319/ lo.2000.45.3.0664

Welch, H., and J. Kalff. 1974. Benthic photosynthesis and respiration in Char Lake. J. Fish. Res. Board Can. 31: 609620. doi:10.1139/f74-093

Wetzel, R. G. 2001. Limnology: Lake and river ecosystems. Academic Press.
Whalen, S., and J. Cornwell. 1985. Nitrogen, phosphorus, and organic carbon cycling in an arctic lake. Can. J. Fish. Aquat. Sci. 42: 797-808. doi:10.1139/f85-102

Whalen, S. C., B. A. Chalfant, and E. N. Fischer. 2008. Epipelic and pelagic primary production in Alaskan Arctic lakes of varying depth. Hydrobiologia 614: 243-257. doi: 10.1007/s10750-008-9510-1

\section{Acknowledgments}

A large number of people contributed to this work over the years. We thank Chris Luecke and the late John O'Brien who helped design the study, and Neil Bettez, Chris Crockett, Dan White, and others on the LTER project who maintained the fertilization over the years and took key limnological measurements. Many other people contributed greatly to this work by helping sample or by providing data and measurements, especially Gretchen Gettel, Marcus Gay, lan Washbourne, Sam Kelsey and Cody Johnson. The manuscript benefited from comments by James Russell and two anonymous reviewers. This project was funded by NSF (NSF-OPP 9732281, NSF-LTER 9810222, 04233855, and 1026843). Additional financial support for WCD came from the Brown-MBL graduate program.

Submitted 15 August 2014 Revised 19 January 2015, 3 February 2015, 6 May 2015 Accepted 11 May 2015

Associate editor: Ronnie Glud 